\title{
Correction to: Obesity: a Ghost at the Feast of the Sustainable Development Goals
}

\author{
Tim Lobstein ${ }^{1,2}$ (D) Katy Cooper ${ }^{3}$ \\ Published online: 23 November 2020 \\ (C) Springer Science+Business Media, LLC, part of Springer Nature 2020

\section{Correction to: Current Obesity Reports https://doi.org/10.1007/s13679-020-00405-x}

The original version of this article unfortunately contained some mistakes in Author's affiliation information, in some areas of the article texts, and references.

The original article has been corrected.

Publisher's Note Springer Nature remains neutral with regard to jurisdictional claims in published maps and institutional affiliations.

The online version of the original article can be found at https://doi.org/ 10.1007/s13679-020-00405-x

\section{Tim Lobstein \\ tlobstein@worldobesity.org}

Katy Cooper

email@katycooper.co.uk

1 World Obesity Federation, Suite 406, 107-111 Fleet Street, London EC4A 2AB, UK

2 Boden Institute, University of Sydney, Camperdown, NSW 2006, Australia

3 UK Working Group on NCDs, London, UK 